\title{
EFEKTIVITAS PERATURAN KEPALA DAERAH TENTANG PENING- KATAN DISIPLIN DAN PENEGAKAN HUKUM PROTOKOL KESEHATAN DI LINGKUNGAN PEMERINTAH DAERAH
}

\section{THE EFFECTIVENESS OF REGIONAL HEAD REGULATION REGARDING DISCIPLINE IMPROVEMENT AND LAW ENFORCEMENT OF HEALTH PROTOCOLS IN THE LOCAL GOVERNMENT ENVIRONMENT}

\author{
Tri Wahyuni \\ Analis Kebijakan \\ Pusat Pelatihan Dan Pengembangan Dan Kajian Desentralisasi Dan Otonomi Daerah \\ LAN RI \\ E-mail : trie_0139@yahoo.com
}

Naskah diterima tanggal 4 Mei 2020. Naskah direvisi tanggal 29 Juni 2020.

Naskah disetujui tanggal 7 Juli 2020

\begin{abstract}
Abstrak
Dari awal keberadaannya hingga saat ini, Covid-19 telah menimbulkan kepanikan. Mendekati akhir Tahun 2020, angka penularan Covid-19 bukan melandai, justru meningkat. Guna menggawang pelaksanaan adaptasi kebiasaan baru, pemerintah telah mengeluarkan kebijakan Inpres No. 6 tahun 2020 tentang Peningkatan Disiplin Dan Penegakan Hukum Protokol Kesehatan Dalam Pencegahan Dan Pengendalian Covid- 2019. Di dalam Inpres disebutkan bahwa Para Gubernur, Bupati, dan Wali kota diperintahkan untuk menyusun dan menetapkan peraturan gubernur/peraturan bupati/wali kota yang memuat kewajiban mematuhi protokol kesehatan serta memuat sanksi terhadap pelanggaran penerapan protokol kesehatan.

Dalam prakteknya, peraturan kepala daerah yang telah disusun, tidak selalu ditaati. Berbagai pelanggaran masih cenderung terjadi. Oleh karenanya, perlu bagi setiap daerah untuk melihat kembali substansi regulasi kepala daerahnya, apakah sudah efektif secara substansi atau belum. Penelitian ini bertujuan untuk melihat efektivitas substansi peraturan kepala daerah tentang penerapan disiplin dan penegakan hukum protokol kesehatan. Penilaian efektivitas didasarkan pada terakomodasi atau tidaknya faktor - faktor dari sebuah konsep implementasi kebijakan di dalam peraturan kepala daerah. Adapun konsep implementasi yang digunakan sebagai dasar penerapan efektivitas, adalah konsep implementasi kebijakan Edward III yang terdiri dari empat unsur kritikal faktor, meliputi : komunikasi, sumber daya, perilaku, dan struktur organisasi. Metode yang digunakan dalam penelitian ini adalah metode kualitatif dengan tipe penelitian deskriptif.
\end{abstract}

Kata Kunci: efektivitas, implementasi kebijakan, Covid-19

\section{Abstract}

Covid-19 has caused panic since it came. At the end of 2020, the Covid-19 transmission rate is not sloping even increasing. In order to surveillance the implementation of new normal, the government has issued a policy of Inpres No. 6 of 2020 dealing with Increasing Discipline and Law Enforcement of Health Protocols in the Prevention and Control of Covid-2019. In the Presidential Instruction it is stated that Governors, Regents and Mayors are instructed to compose and stipulate governor regulations / regent / mayor regulations which contain the obligation to obey the health protocol and get penalty for violating the implementation of health protocols.

In fact, regional head regulations that have been drafted are not always obeyed. Many violations still tend to occur. Therefore, it is necessary for each region to review the core of its regional head regulations, whether it is substantially effective or not. This study aims to see the effectiveness of the substance of regional head regulations regarding the implementation of discipline and law enforcement of health protocols. The effectiveness assessment is based on whether or not factors from a policy implementation concept are accommodated in the regional head regulation. The implementation concept used as the fundamental for implementing 
effectiveness is the concept of implementing Edward III's policy which consists of four critical element factors, including: communication, resources, behavior, and organizational structure. The method used in this research is a qualitative method with descriptive research type.

Keywords: effectiveness, policy implementation, Covid-19

\section{PENDAHULUAN}

Medio Tahun 2020, Organisasi Kesehatan Dunia (WHO) menyebut, sejak dunia pertama kali menemukan dan menghadapi virus Corona Covid-19, virus ini sudah menginfeksi lebih dari 10 juta orang dan menyebabkan sekitar 500 ribu kematian (health.detik.com, 2020). Di Indonesia, Penyakit yang disebabkan oleh infeksi virus, dengan sebutan Covid-19 telah memakan banyak korban. Di bulan Oktober, tercatat kasus positif Covid-19 mencapai 328.952 kasus, dari jumlah tersebut 251.481 orang sembuh, dan 11.765 meninggal dunia. Data Satgas Covid-19 juga menunjukkan sebanyak 54 Kabupaten/Kota di Indonesia berada di zona merah. Artinya, di wilayah itu penyebaran virus tak terkendali. Sebanyak 304 Kabupaten/Kota berada di zona oranye atau zona risiko tinggi penyebaran (CNN Indonesia, 2020). Kini, mendekati akhir Tahun 2020, angka penularan bukan melandai, justru meningkat. Pada 11 Desember, Satuan Tugas Penanganan COVID-19 mencatat ada penambahan 175 kematian dalam sehari. Jumlah ini merupakan rekor tertinggi sepanjang pandemi melanda Indonesia. Juru Bicara Satgas Penanganan COVID-19 Wiku Adi Sasmito mengatakan angka kematian nasional mingguan meningkat 15,5 persen (Tirto.id, 2020).

Pada awal kedatangannya, di tengah kepanikan dan keterbatasan informasi dari hasil penelitian atas virus Covid-19, kebijakan yang diambil sebagian besar negara di dunia, hampir sama, yakni, pembatasan aktivitas sosial, hingga muncul istilah lockdown. Pada masa awal tersebut, berbagai kegiatan kehidupan masyarakat, mengalami perubahan pola interaksi: mulai dari kegiatan pendidikan, sosial, ekonomi, hingga kegiatan beragama. Tindakan pembatasan interaksi sosial diambil, karena dirasa efektif dapat menekan laju penambahan jumlah orang yang terinfeksi. Semakin interaksi terbatas, dianggap semakin mampu mengurangi potensi jumlah orang yang terinfeksi. Hingga saat ini, kegiatan belajar dan bekerja dari rumah bagi sebagian orang masih tetap berjalan dengan baik. Namun tidak bagi sebagian yang lain. Pembatasan aktivitas di luar rumah bisa berarti matinya mata pencaharian bagi sebagian masyarakat, terutama yang bekerja di sektor informal. Berdasarkan data Survei Angkatan Kerja Nasional Badan Pusat Statistik 2019, Mayoritas penduduk Indonesia bekerja di kegiatan informal sebesar $55,72 \%$. Sementara yang bekerja di sektor formal sebesar 44,28\% (BPS, 2019). Jika para pekerja di sektor informal dipaksa untuk tetap tinggal di rumah, itu artinya tidak ada yang bisa mereka kerjakan, karena pekerjaan mereka ada di jalan, laut, udara, pabrik ataupun pasar.

Situasi yang saling berhadapan antara persoalan kesehatan dan ekonomi, menggiring pada lahirnya sebuah kebijakan bernama new normal (era normal baru). Menurut Juru Bicara Penanganan Covid-19, Achmad Yurianto "Satu-satunya cara yang kita lakukan bukan dengan menyerah tidak melakukan apapun, melainkan kita harus jaga produktivitas kita agar dalam situasi seperti ini kita produktif namun aman dari Covid-19, sehingga diperlukan tatanan yang baru." Lebih lanjut menurut Yuri, tatanan, kebiasaan dan perilaku yang baru berbasis pada adaptasi untuk membudayakan perilaku hidup bersih dan sehat inilah yang kemudian disebut sebagai new normal. (Tirto, 2020). Dalam perjalanan waktu, penggunaan diksi new normal selama pandemi Covid-19 dinilai sulit dipahami oleh masyarakat. Akibatnya, pemerintah mengubah diksi tersebut menjadi adaptasi kebiasaan baru. Guna menggawang pelaksanaan adaptasi kebiasaan baru, pemerintah mengeluarkan 
kebijakan melalui Inpres No. 6 tahun 2020 tentang Peningkatan Disiplin Dan Penegakan Hukum Protokol Kesehatan Dalam Pencegahan Dan Pengendalian Covid- 2019. Kehadiran Inpres diharapkan dapat efektif memberikan arahan bagi seluruh daerah di Indonesia dalam peningkatan dan penegakan hukum protokol kesehatan. Juru bicara Presiden Bidang Hukum, Dini Purwono menjelaskan, Inpres ini diterbitkan untuk memberikan landasan hukum bagi upaya penanganan situasi pandemi Covid-19. Serta meningkatkan kedisiplinan masyarakat dalam melaksanakan protokoler kesehatan yang sudah ditetapkan. "Inpres ini membuktikan keseriusan pemerintah untuk menekan angka penyebaran Covid-19 (Liputan 6.com, 2020).

Masyarakat yang adaptif dengan kebiasaan baru merupakan harapan yang ingin diwujudkan melalui substansi Inpres No. 6 yang ditetapkan pada tanggal 4 Agustus 2020. Guna lebih mengefektifkan penerapan disiplin dan penegakan protokol di seluruh wilayah Indonesia, di dalam Inpres disebutkan bahwa Para Gubernur, Bupati, dan Wali kota diperintahkan untuk menyusun dan menetapkan peraturan gubernur/peraturan bupati/wali kota yang memuat kewajiban mematuhi protokol kesehatan kepada perorangan, pelaku usaha, pengelola, penyelenggara, atau penanggung jawab tempat dan fasilitas umum serta memuat sanksi terhadap pelanggaran penerapan protokol kesehatan dalam pencegahan dan pengendalian Covid-19.

Namun demikian, di dalam prakteknya, peraturan kepala daerah tentang penerapan protokol kesehatan dan pelaksanaan aktivitas secara normal, tidak selalu ditaati. Berbagai pelanggaran oleh masyarakat masih cenderung terjadi. Gubernur Jawa Barat Ridwan Kamil mengungkapkan, tercatat sudah ada 590.858 ribu total pelanggaran protokol kesehatan hingga 29 Agustus 2020 (Liputan6.Com, 2020). Di Jawa Tengah, Satuan Polisi Pamong Praja Kabupaten Kudus, mencatat jumlah kasus pelanggaran protokol kesehatan sejak diberlakukannya Peraturan Bupati nomor 41/2020 tentang Penerapan Disiplin dan Penegakan Hukum Protokol Kesehatan mencapai 4.574 kasus (Republika, 2020). Di bagian lain Pulau Sumatra (Kota Pekanbaru), total selama empat hari terjaring 332 pelanggar. Plt Kepala Satpol PP Kota Pekanbaru membenarkan terjadi peningkatan jumlah warga yang ditindak akibat melanggar protokol kesehatan, yakni tidak mengenakan masker. (Riaupos, 2020).

Dengan masih tingginya kasus penyebaran Covid-19 hingga saat ini, perlu bagi setiap daerah untuk melihat kembali kegiatan implementasi penerapan protokol di daerahnya dari berbagai aspek. Salah satunya terkait substansi regulasi kepala daerah yang telah dibuat tentang penerapan protokol. Hal ini sebagaimana yang tersirat dari pernyataan Satgas Covid19 yang meminta kepala daerah mengevaluasi implementasi protokol kesehatan yang dilakukan pemerintah dan masyarakat serta penegakan disiplin terkait protokol kesehatan yang dilakukan Satgas di daerah dengan adanya peningkatan kasus di DKI dan Jawa Tengah (Beritasatu, 2020). Inpres No. 6/2020 dengan substansi yang detail tentang aktor kebijakan yang terlibat dan bagaimana bentuk koordinasin sebagai sebuah sistem kerja,seharusnya diikuti juga oleh peraturan kepala daerah dengan harapan untuk mempermudah implementasi di lapangan. Regulasi penegakan disiplin dan penerapan protokol dibuat dalam upaya menekan angka penyebaran Covid-19. Regulasi yang dibuat dengan muatan pengaturan yang tidak eksplisit, tidak terstruktur, hanya terkesan menggugurkan kewajiban, tentu dapat berimplikasi pada ketidak efektivan dari maksud penerbitannya. Pelanggaran dapat terus terjadi, karena aparatur tidak dapat mengambil tindakan secara konkrit tentang apa yang harus dilakukan sebagaimana yang seharusnya diatur di dalam regulasi. Pada akhirnya, tidak sedikit warga tidak lagi memakai masker saat ini. Termasuk rendahnya pengawasan aparat pemerintah di lapangan.

Peraturan kepala daerah yang 
operasional akan sangat membantu dalam memandu penerapan disiplin dan penegakan hukum protokol kesehatan. Keberadaannya diharapkan akan mampu mencegah orang untuk tidak berdisiplin dan mereduksi terjadinya pelanggaran. Dengan demikian, akan tercapai tujuan dari penerbitan regulasi peraturan kepala daerah sebagaimana harapan dari Inpres No. 6 Tahun 2020. Masyarakat yang disiplin pada protokol, merupakan harapan dari diterbitkannya regulasi peraturan kepala daerah, karena tingkat abtraksi yang paling tinggi, dari dampak implementasi, telah ada perubahan yang bisa diukur dalam masalah yang luas yang dikaitkan dengan program, undang-undang publik, dan keputusan yudisial (Winarno, 2012 : 148)

Penelitian ini bertujuan untuk melakukan analisis terhadap efektivitas substansi sebuah peraturan kepala daerah tentang penerapan disiplin dan penegakan hukum protokol kesehatan . Peraturan kepala daerah yang efektif diharapkan dapat memperkuat upaya penerapan disiplin dan penegakan hukum protokol di tengah kasus penyebaran Covid-19 yang terus meningkat. Penilaian efektivitas didasarkan pada terakomodasi atau tidaknya faktor - faktor dari sebuah konsep implementasi kebijakan yang diterapkan di dalam pasal-pasal peraturannya. Hasil analisis Adapun konsep implementasi yang digunakan sebagai dasar penerapan efektivitas, adalah konsep implementasi kebijakan Edward III (1980)yang memberikan penekanan kepada empat unsur kritikal faktor yang meliputi : komunikasi, sumber daya, perilaku, dan struktur organisasi. Hasil dari analisis atas efektivitas substansi peraturan bupati diharapkan dapat membantu mengurangi kegagalan/kurang optimalnya pemberlakuan peraturan kepala daerah sebagai payung hukum operasionalisasi atas penerapan disiplin dan penegakan protokol. Adapun peraturan kepala daerah yang akan menjadi objek dalam penelitan ini antara lain : Peraturan Bupati Boalemo, Peraturan Bupati Klaten, Peraturan Bupati Bone, Peraturan Bupati Situbondo dan Peraturan Bupati
Kabupaten Belitung Timur.

\section{METODOLOGI PENELITIAN}

Penelitian ini merupakan penelitian deskriptif (penggambaran), yaitu suatu penelitian yang mendeskripsikan apa yang terjadi pada saat melakukan penelitian. Di dalamnya terdapat upaya mendeskripsikan, mencatat, menganalisa dan menginterprestasikan kondisi - kondisi yang sekarang ini terjadi atau ada (Pasolong, 2013 : 75 - 76). Jenis penelitian ini dianggap tepat digunakan, karena Peneliti ini berupaya untuk menggambarkan secara komprehensif terkait substansi regulasi penerapan disiplin dan penegakan protokol kesehatan yang menjadi fokus penelitian serta memberikan gambaran berbagai kondisi dan upaya penanganan penyebaran Covid19 saat ini. Adapun pendekatan penelitian dilakukan dengan menggunakan pendekatan kualitatif. Penelitian kualitatif didefinisikan sebagai jenis penelitian yang temuan-temuannya tidak diperoleh melalui prosedur statistik atau bentuk hitungan lainnya" (Strauss dan Corbin dalam Afrizal 2015).

Temuan dalam penelitian didapatkan dari pengumpulan studi pustaka, seperti : buku, jurnal, peraturan perundangan terkait peningkatan disiplin dan penegakan hukum protokol kesehatan Covid-19, serta kasus pelanggaran protokol kesehatan dari situs berita online yang dianggap relevan dengan topik yang akan dibahas selama dilakukannya penelitian ini. Teknik Analisis Data dalam penelitian ini dilakukan seperti yang disampaikan oleh Miles dan Huberman : mereduksi data, menyajikan data, dan menarik kesimpulan (Afrizal, 2015. Hal. 174). Reduksi data dilakukan dengan memisahkan dan menentukan antara data yang dianggap penting dan tidak penting . Kegiatan penyajian dilakukan dengan menyajikan semua informasi yang telah tersusun secara sistematis. Adapun kesimpulan dilakukan dengan memberikan tafsiran dari hasil analisa yang telah dilakkan. Teori dan konsep yang akan digunakan dalam penelitian ini adalah teori/konsep 
yang berkaitan dengan implementasi kebijakan. Adapun fokus dari penelitian ini adalah Analisis terhadap teori, konsep dan regulasi terhadap penguatan peraturan bupati tentang peningkatan disiplin dan penegakan hukum protokol kesehatan di lingkungan pemerintah daerah.

\section{TINJAUAN PUSTAKA}

\section{Kerangka Konsep}

Mengiringi adaptasi kebiasaan baru, pemerintah menerbitkan regulasi berupa instruksi presiden No. 6 tahun 2020 Tentang Peningkatan Disiplin dan Penegakan Hukum Protokol Kesehatan dalam Pencegahan dan Pengendalian Corona Virus 2019. Karakteristik instruksi sangat sesuai dari aspek hukum dalam kasus penanganan Covid-19, karena sifatnya lebih mengarahkan. Hal tersebut senada dengan apa yang disampaikan oleh Jimly Asshiddiqie (tahun?), b ahwa instruksi presiden, merupakan "policy rules" atau "beleidsregels", yaitu bentuk peraturan kebijakan yang tidak dapat dikategorikan sebagai bentuk peraturan perundang-undangan yang biasa. Berdasarkan uraian tersebut, instruksi presiden hanya terbatas untuk memberikan arahan, menuntun, membimbing dalam hal suatu pelaksanaan tugas dan pekerjaan (Hukum Online, 2012). Kesesuaian lain atas Penerbitan Inpres No. 6 Tahun 2020 dalam mengatasi pandemik, sebagaimana satu dari tiga alasan yang dikemukakan oleh Bagir Manan, yakni : menunjang perubahan masyarakat yang cepat, mendorong administrasi negara berperan lebih besar dalam pembentukan peraturan perundang-undangan (Dewa, 2011:75).

Instruksi Presiden Republik Indonesia nomor 6 tahun 2020 Tentang Peningkatan Disiplin dan Penegakan Hukum Protokol Kesehatan Dalam Pencegahan dan Pengendalian Covid-19 ditujukan diantaranya kepada Para Gubernur; dan Para Bupati/Wali kota. Semua elemen bangsa dilibatkan dalam upaya Peningkatan Disiplin dan Penegakan Hukum Protokol Kesehatan Dalam Pencegahan dan Pengendalian Covid-19. Kepada Panglima TNI dan
Kepala Kepolisian diarahkan untuk memberikan dukungan kepada gubernur,bupati/wali kota dengan mengerahkan kekuatannya untuk melakukan pengawasan pelaksanaan protokol kesehatan di masyarakat, menggiatkan patroli penerapan protokol kesehatan di masyarakat; dan pembinaan masyarakat untuk berpartisipasi dalam upaya pencegahan dan pengendalian Covid -19. Para Gubernur, Bupati, dan Wali kota diharapkan dapat meningkatkan sosialisasi secara masif penerapan protokol kesehatan dalam pencegahan dan pengendalian COVID-I9 dengan melibatkan masyarakat, pemuka agama, tokoh adat, tokoh masyarakat, dan unsur masyarakat lainnya serta menyusun dan menetapkan peraturan gubernur/peraturan bupati/wali kota

Salah satu pasal dalam Inpres menyebutkan tentang kewajiban membuat Peraturan gubernur/peraturan bupati/wali kota yang memuat ketentuan antara lain: kewajiban mematuhi protokol kesehatan yang dikenakan kepada perorangan, pelaku usaha, pengelola, penyelenggara, atau penanggung jawab tempat dari fasilitas umum. Peraturan kepala daerah juga harus memuat sanksi terhadap pelanggaran penerapan protokol kesehatan dalam pencegahan dan pengendalian Covid-19) yang dilakukan oleh perorangan, pelaku usaha, pengelola, penyelenggara, atau penanggung jawab tempat dan fasilitas umum. Respon cepat atas Inpres, beberapa pemerintah daerah menerbitkan Peraturan bupati, diantaranya : Perbup Belitung Timur No. 44 Tahun 2020, Perbup Bone No. 37 Tahun 2020, Perbup Boalemo No. 60 Tahun 2020, Perbup Klaten No. 40 Tahun 2020, serta Perbup Situbondo No. 45 Tahun 2020.

Untuk melihat apakah peraturan yang telah dibuat sudah efektif atau tidak dari sisi substansi, maka dapat dilihat dari terpenuhi atau tidaknya unsur - unsur yang ada dalam konsep implementasi kebijakan di dalam regulasi tersebut. Terdapat beberapa konsep tentang implementasi kebijakan, diantaranya konsep yang disampaikan oleh Donald Van Meter dengan Van Horn (1975), model ini 
mengandaikan bahwa implementator kebijakan berjalan secara linier dari keputusan politik. Model ini menegaskan bahwa terdapat enam variabel yang mempengaruhi dalam proses kebijakan : standar dan sasaran kebijakan/ukuran dan tujuan kebijakan, sumber daya, karakteristik organisasi pelaksana, sikap para pelaksana, komunikasi antar organisasi terkait dan kegiatan pelaksana, serta lingkungan sosial, ekonomi dan politik (Kurniawan, dkk, 2018). Ada juga model Jan Merse) yang mengemukakan empat Model implementasi kebijakan, yakni : informasi, Isi kebijakan, dukungan masyarakat (fisik dan non fisik), dan pembagian potensi (Arundinasari,dkk, 2019). Model lainnya seperti apa yang disampikan oleh Edward III (1980) yang mengidentifikasi bahwa terdapat empat kritikal faktors yang mempengaruhi keberhasilan implementasi. Keempat faktor tersebut adalah: komunikasi, sumber daya, disposisi atau perilaku, dan struktur birokrasi (Purwanto dan Sulistyastuti, $2012: 85)$.

Komunikasi adalah apa yang menjadi tujuan dan sasaran kebijakan harus ditransmisikan kepada kelompok sasaran (target group) sehingga dapat mengurangi distorsi implementasi (Subarsono (2013) dalam Zahrah dan Hidayat, 2017). Melalui komunikasi, eksekutif pemerintah atau administrator atau manajer pemerintah bermaksud untuk mempengaruhi

(attitude), sikap dan perilaku (behavior) (understanding), dan perilaku (behavior) birokrasi dan masyarakat. Komunikasi pemerintahan ekternal organisasi dimaksudkan untuk mengirim informasi publik (publik information) oleh administrator/aparatur kepada masyarakat dan sektor swasta (private sector) atau sektor bisnis (business sector) (Silalahi, 2004). Komunikasi yang berkaitan dengan proses sosialisasi adalah komunikasi sosial. Komunikasi sosial merupakan suatu proses sosialisasi untuk menciptakan pencapaian stabilitas sosial, tertib sosial, penerusan nilai-nilai lama dan baru yang diagungkan oleh suatu masyarakat dipupuk, dibina dan diperluas (Priansa
2017) dalam Mugni dan Harjoni, (2020). Sosialisasi bisa berupa penyuluhan atau pemberian informasi yang dilakukan baik secara langsung maupun tidak langsung, dapat melalui tatap muka maupun berbagai media pendukung lainnya media cetak, media elektronik, media luar ruang, media internet, media sosial dan lainnya (Ryndang, dkk, 2020).

Komunikasi berbasis jaringan dapat menjadi alternatif. Di Indonesia, pengguna internet mencapai 150 juta jiwa dengan penetrasi $56 \%$ yang tersebar diseluruh wilayah. Jumlah tersebut hanya selisih sedikit dengan jumlah pengguna internet mobile yang berjumlah 142.8 juta jiwa dengan persentase penetrasi sebesar 53\% (Kominfo.go.id, 2019). Pesan komunikasi yang jelas tentang COVID-19 melalui media resmi dan media sosial merupakan kontributor penting untuk mengubah perilaku masyarakat terhadap penggunaan masker, mencuci tangan, dan menjaga jarak social (Engkus, Suparman, Sakti, Anwar, 2020). Penggunaan media sosial diharapkan dapat mendekatkan hubungan dengan masyarakat yang pada akhirnya meningkatkan partisipasi masyarakat dan meningkatkan reputasi pemerintah daerah. Media sosial berbeda dengan media lain salah satunya karena media sosial mampu memberikan kecepatan informasi. Akan tetapi kecepatan informasi ini juga menuntut sumber daya manusia yang dinamis dan adaptif. (Purworini, D, 2017). Kritikal faktor kedua adalah sumber daya. Meskipun implementing agency yang terlibat dalam implementasi kebijakan publik bisa sangat beragam, akan tetapi birokrasi sampai saat ini masih memiliki posisi yang paling dominan dibanding dengan organisasi yang lain. (Purwanto dan Sulistyastuti, 2012 : 128). Apabila implementator kekurangan sumber daya untuk melaksanakan, implementasi tidak akan berjalan efektif. Sumber daya tersebut dapat berwujud sumber daya manusia, yakni kompetensi implementor, dan sumber daya finansial (Subarsono (2013) dalam Zahrah dan Hidayat, 2017). Kritikal faktor ketiga adalah perilaku atau disposisi. Disposisi adalah watak dan karakteristik yang dimiliki oleh 
implementor, seperti komitmen, kejujuran, sifat demokratis. Apabila implementor memiliki disposisi yang baik, maka dia akan dapat menjalankan kebijakan dengan baik seperti apa yang diinginkan oleh pembuat kebijakan (Subarsono (2013) dalam Zahrah dan Hidayat, 2017). Kritikal faktor keempat adalah Organisasi. Implementasi yang berhasil merupakan fungsi dari kemampuan organisasi pelaksana untuk melakukan apa yang diharapkan untuk dikerjakan. Kemampuan untuk melaksanakan kebijakan-kebijakan mungkin dihambat oleh faktor-faktor seperti staf yang kurang terlatih dan terlalu banyak pekerjaan, informasi yang tidak memadai dan sumber-sumber keuangan atau hambatan-hambatan waktu yang tidak memungkinkan (Van Meter dan Van Horn (1975) dalam Winarno, 2012 : 173-174). struktur birokrasi, Struktur organisasi yang bertugas mengimplementasikan kebijakan memiliki pengaruh yang signifikan terhadap implementasi kebijakan. Salah satu dari aspek struktur yang penting dari setiap organisasi adalah adanya prosedur operasi yang standar (Standard Operating Procedures atau SOP). Keempat variabel tersebut juga saling berhubungan satu sama lain (Subarsono dalam Zahrah dan Hidayat, 2017).

\section{Riset Terdahulu}

Penerapan kebijakan pencegahan dan pengendalian Covid-19 merupakan proses mewujudkan kesadaran tentang kedisplinan dan penegakan hukum protokol kesehatan yang tidak mudah untuk dipatuhi. Perilaku tidak normal ditunjukkan oleh masyarakat Indonesia. Di tengah pandemi covid 19 di Indonesia yang semakin banyak menunjukkan kasus positif, masyarakat seakan tidak takut dan memilih untuk berlibur, jalan-jalan ke pusat perbelanjaan, mengadakan tabligh akbar, dan kegiatan lain yang dilakukan secara berkerumun. Hal ini tentunya bertolak belakang dengan himbauan pemerintah untuk melakukan social distancing dan tetap dirumah (Harirah,2020).

Harus diakui bahwa penyebaran Covid 19 di Indonesia menjadi tantangan bagi Pemerintah untuk menunjukkan eksistensinya dalam memastikan kesehatan dan kesejahteraan masyarakat secara bersamaan. Berbagai kebijakan pemerintah diukur efektivitasnya, masyarakat dinilai ketaatannya. Harmonisasi keduanya menjadi penentu keberhasilan penanganan Covid 19 di Indonesia (Harirah, 2020). Sejauh pemerintah dapat menyiapkan skema kebijakan yang baik (good policies) untuk mencegah dan mengatasi dampak yang ditimbulkan oleh virus Corona kepada masyarakat, maka sejauh itu pula pemerintah dianggap berhasil menjalankan fungsinya sebagai pemerintah yang baik (good government) dan tata kepemerintahan yang baik (good governance) di era pandemic COVID-19 (Tuwu, 2020). COVID-19 telah memunculkan adopsi berbagai kebijakan publik oleh pemerintah, dengan berbagai desain dan konten kebijakan yang beragam (Engkus, Suparman, Sakti, Anwar, 2020).

\section{Pembahasan}

Jumlah kasus terkonfirmasi Covid$19 \mathrm{di}$ Tanah Air terus mengalami peningkatan hingga awal Desember. Pemerintah mengumumkan adanya penambahan 6.089 kasus baru. Dengan begitu, sejak pengumuman kasus perdana pada 2 Maret 2020, Indonesia memiliki 575.796 kasus Covid-19 (Kompas.Com, 2020). Masa pandemik yang panjang membawa dampak pada berbagai aspek kehidupan, termasuk ekonomi dan kerentanan sosial. Dampak kerentanan sosial dapat membuat masyarakat melakukan tiga tindakan yang saling terkait, yaitu tindakan apatis, tindakan irasional, dan tindakan kriminal. Pada tindakan apatis bisa kita lihat pada tindakan masyarakat yang tidak peduli dengan instruksi pemerintah untuk physical distancing (Kompas, 2020). Dampak perekonomian, tidak hanya di rasakan secara domestik,namun juga terjadi secara global. International Monetary Fund (IMF) yang memproyeksikan ekonomi global akan tumbuh minus di angka 3\%. Di Indonesia,hal ini tentunya juga memiliki dampak yang cukup signifikan 
terhadap pariwisata, sektor perdagangan,industri termasuk Pelaku Usaha Mikro, Kecil dan Menengah (UMKM). Di Indonesia, berdasarkan data terbaru pertanggal 04 Mei 2020, sudah terdapat 11.192 kasus covid - 19 di Indonesia (Covid19.go.id) Dampak dari covid - 19 secara langsung sudah terlihat dari PHK besar - besaran dibeberapa perusahaan, terjadi penutupan beberapa usaha yang berdampak kepada dirumahkannya karyawan (Hardilawati, 2020). Berada di situasi dilematis antara prioritas kesehatan dan ekonomi, pemerintah mengeluarkan kebijakan adaptasi kebiasaan baru sebagai jalan keluar untuk menyelamatkan ekonomi.

Pada saat Indonesia bersiap memasuki masa kenormalan baru, kasus virus corona justru semakin meningkat. Menurut Fajar Junaedi, dosen Ilmu Komunikasi Universitas Muhammadiyah Yogyakarta, pemahaman permasalahan diperlukan dalam upaya pengendalian virus Corona penyebab Covid-19. Masyarakat perlu banyak dilibatkan agar dapat memahami risiko dari penyakit Covid-19. Hal lain yang paling penting juga untuk dilakukan, masyarakat dapat mematuhi anjuran protokol kesehatan yang telah dibuat (Kompas, 2020). Guna memaksimalkan penerapan adaptasi kebiasaan baru, pemerintah mengeluarkan regulasi berupa Inpres No. 6 Tahun 2020 Tentang Peningkatan Disiplin dan Penegakan Hukum Protokol Kesehatan Dalam Pencegahan dan Pengendalian Covid-19. Inpres No. 6 tahun 2020 mempunyai Proses perencanaan implementasi kebijakan yang terstruktur, dimulai dari penentuan aktor kebijakan yang lengkap, yang terdiri atas : Para Menteri Kabinet Indonesia Maju, Sekretaris Kabinet, Panglima Tentara Nasional Indonesia, Kepala Kepolisian Negara Republik Indonesia, Para Kepala Lembaga Pemerintah Non Kementerian, Para Gubernur; dan Para Bupati/Walikota. Ketujuh aktor kebijakan ditugaskan mengambil langkah-langkah yang diperlukan sesuai tugas,fungsi, dan kewenangan masing-masing dalam menjamin kepastian hukum yang tersebut di dalam Inpres.

Disamping aktor, prosedur kerja sesuai dengan struktur masing-masing aktor kebijakan juga diatur di dalam Inpres No. 6 Tahun 2020. Terdapat prosedur Penjelasan Khusus kepada Tugas Menteri Koordinator Bidang Politik, Hukum, dan Keamanan untuk melakukan koordinasi, sinkronisasi, dan Pengendalian. Menteri Dalam Negeri bertugas melaksanakan sosialisasi dan diseminasi secara masif dan memberikan pedoman. Kepala Badan Nasional Penanggulangan Bencana bertugas melaksanakan monitoring dan evaluasi atas pelaksanaan pengenaan sanksi. Panglima Tentara Nasional Indonesia dan Kepala Kepolisian Negara Republik Indonesia bertugas memberikan dukungan kepada kepala daerah. Sementara, para Gubernur, Bupati, dan Wali kota bertugas menyusun dan menetapkan peraturan.

Dalam salah satu ketentuannya, Inpres No. 6 tahun 2020 menginstruksikan kepada para kepala daerah untuk membuat regulasi turunan terkait kewajiban mematuhi protokol kesehatan kepada perorangan, pelaku usaha, pengelola, penyelenggara, atau penanggung jawab tempat dan fasilitas umum serta memuat sanksi terhadap pelanggaran penerapan protokol kesehatan dalam pencegahan dan pengendalian Covid-19. Gambaran perencanaan implementasi yang terstruktur terkait aktor dan prosedur kerja di Inpres No 6 tahun 2020, seharusnya juga tertuang di dalam peraturan kepala daerah, bahkan, jika memungkinkan, Peraturan kepala daerah sebagai aturan turunan, harus lebih detail daripada yang tersebut di dalam Inpres. Dengan demikian, di dalam peraturan kepala daerah, harus mengatur tentang siapa saja aktor yang terlibat dalam implementasi peraturan kepala daerah, serta bagaimana desain operasional kebijakan yang harus dilakukan. Harus tergambarkan dengan jelas di dalam peraturan kepala daerah tentang apa saja tindakan preventif dan represif yang harus diatur, dari tataran konsep hingga operasional. Dengan substansi yang jelas dan bernas, peraturan kepala daerah akan dapat berjalan efektiv. Efektivitas 
merupakan kemampuan untuk memilih tujuan dengan memanfaatkan sarana dan prasarana yang tepat untuk mencapai tujuan dengan tepat dan cepat, dengan pencapaian berhasil dan ataupun gagal ( Campbell J.P. (1970) dalam Lestanata, 2016).

Peraturan kepala daerah dapat dikatakan efektif jika dalam pencapaian tujuannya dapat memanfaatkan sarana dan prasarana yang tepat. Tujuan dari penerbitan kepala daerah adalah dalam upaya mereduksi penyebaran Covid-19. Adapun sarana yang dapat digunakan untuk mencapai efektifitas dari regulasi peningkatan disiplin dan penegakan protokol kesehatan adalah empat kritikal faktor implementasi kebijakan (dalam hal ini sebagaimana yang dikemukakan oleh Edward III). Edward III (1980) mengidentifikasi empat kritikal faktor yang mempengaruhi keberhasilan implementasi. Keempat faktor tersebut adalah: komunikasi, sumber daya, disposisi atau perilaku, dan struktur birokrasi (Purwanto dan Sulistyastuti, 2012 : 85). Konsep Edward III digunakan sebagai alat analisis dalam penelitian ini, karena empat kritikal faktor yang ada di dalamnya menurut penulis sangat sesuai untuk menggambarkan peta stakeholder dan peta koordinasi, sebagai dasar penilaian efektivitas proses implementasi peningkatan disiplin dan penegakan protokol. Ketika ada yang kurang satu saja dari empat kritikal faktor di dalam substansi peraturan kepala daerah, maka, implemantasinya dikhawatirkan tidak efektif. Berkurangnya salah satu kritikal faktor dikhawatirkan dapat menyebabkan kegagapan dalam implementasi peraturan kepala daerah.

Tidak adanya kritikal faktor komunikasi dapat menghambat proses sosialisasi kebijakan tentang mitigasi penyebaran Covid-19. Dalam faktor ini, eksekutif pemerintah atau administrator atau manajer pemerintah bermaksud untuk mempengaruhi sikap (attitude), pemahaman (understanding), dan perilaku (behavior) birokrasi dan masyarakat. Dengan demikian, tiap orang yang terlibat dalam penyelenggaraan pemerintahan demokratis merupakan bagian dari proses komunikasi pemerintahan (Silalahi, 2004). Komunikasi oleh pemerintah, dilakukan melalui dua sisi. Komunikasi dari sisi internal, dilakukan di dalam organisasi sendiri (baik secara vertikal maupun horizontal), dan komunikasi dari sisi eksternal. Komunikasi pemerintahan ekternal organisasi dimaksudkan untuk mengirim informasi publik (publik information) oleh administrator/aparatur kepada masyarakat dan sektor swasta (private sector) atau sektor bisnis (business sector) (Silalahi, 2004). Komunikasi internal terkait penanganan Covid-19 di dalam peraturan kepala daerah, dapat dilakukan melalui gambaran koordinasi antara perangkat daerah teknis (Dinkes) dan perangkat daerah lain yang bersifat pendukung. Adapun komunikasi pemerintah secara eksternal, dapat dilakukan melalui kegiatan sosialisasi. Sosialisasi adalah komunikasi sosial,merupakan suatu proses sosialisasi untuk menciptakan pencapaian stabilitas sosial, tertib sosial, penerusan nilai-nilai lama dan baru yang diagungkan oleh suatu masyarakat dipupuk, dibina dan diperluas (Priansa dalam Mugni dan Harjoni, 2020). Materi tentang Covid-19 yang mungkin masih tidak terpahami dengan baik bagi sebagian orang, disampaikan di forum sosialisasi, karena sosialisasi merupakan proses belajar seorang untuk mempelajari hal yang baru agar dapat mengenal dan memahami dengan sangat dalam sebuah kebaruan. Dalam prakteknya, sosialisasi bisa berupa penyuluhan atau pemberian informasi yang dilakukan baik secara langsung maupun tidak langsung, dapat melalui tatap muka maupun berbagai media pendukung lainnya media cetak, media elektronik, media luar ruang, media internet, media sosial dan lainnya (Ryndang, 2020).

Seiring dengan perkembangan jaman, penggunaan tekhnologi dapat menjadi alternatif dalam pelaksanaan sosialisasi, terlebih dengan kondisi Indonesia, dimana pengguna internet mencapai 150 juta jiwa dengan penetrasi $56 \%$ yang tersebar diseluruh wilayah. Jumlah tersebut hanya selisih sedikit dengan jumlah pengguna internet mobile yang berjumlah 142.8 juta 
jiwa dengan persentase penetrasi sebesar 53\% (Kominfo.go.id, 2019). Penggunaan media sosial dapat dipertimbangkan dalam menyampaikan pesan penerapan disiplin terhadap protokol kesehatan. Pesan komunikasi yang jelas tentang COVID-19 melalui media sosial resmi pemerintah dan media sosial merupakan kontributor penting untuk mengubah perilaku masyarakat terhadap penggunaan masker, mencuci tangan, dan menjaga jarak social (Engkus, Suparman, Sakti, Anwar, 2020). Penggunaan media sosial yang menyesuaikan dengan karakteristik masyarakat, diharapkan dapat lebih efektif dalam menyampaikan pesan. Penggunaan media sosial diharapkan juga dapat mendekatkan hubungan dengan masyarakat yang pada akhirnya meningkatkan partisipasi masyarakat dan meningkatkan reputasi pemerintah daerah. (Purworini, D, 2017).

Kurangnya kritikal faktor terkait sumber daya dapat menyebabkan lambannya penerapan regulasi, karena tugas hanya menjadi beban satu atau dua perangkat daerah. Sumber daya birokrasi sangat menentukan suksesnya sebuah implementasi, baik dari segi jumlah maupun kompetensi (Purwanto dan Sulistyastuti, 2012 : 128). Semakin banyak perangkat daerah yang dilibatkan, akan semakin membantu proses implementasi. Karena penanganan masalah Covid-19 merupakan masalah yang kompleks, maka pemecahannya tidak bisa lagi bersifat uni sektoral saja (diserahkan pada satu departeman, lembaga, atau dinas) tetapi harus multi sektoral (melibatkan berbagai lembaga dan dipecahkan dari berbagai arah). Dalam perkembangan jaman, struktur untuk implementasi kebijakan akan lebih bersifat kompleks daripada sederhana (Purwanto dan Sulistyastuti, 2012 : 134). Dalam upaya penguatan SDM, Panglima TNI dan Kepala Kepolisian diarahkan untuk memberikan dukungan kepada kepala daerah dengan mengerahkan kekuatannya untuk melakukan pengawasan pelaksanaan protokol kesehatan di masyarakat. Hal ini untuk membantu mengatasi kondisi jika terdapat keterbatasan pelaksana di lapangan. Implementator kekurangan sumber daya untuk melaksanakan, implementasi tidak akan berjalan efektif. Sumber daya tersebut tidak saja berwujud sumberdaya manusia, tapi juga kompetensi implementor, dan sumber daya finansial (Subarsono dalam Zahrah dan Hidayat, 2017. Semakin banyak perangkat implementator yang terlibat, juga akan lebih mensinergikan aspek finansial yang selama ini selalu menjadi kendala dalam proses implementasi kebijakan. Jika hanya satu atau dua perangkat daerah yang terlibat, terkadang sering ada masalah di keterbatasan penganggaran, karena kegiatan yang besar, tidak selalu diimbangi dengan penganggaran yang besar juga. Begitupun dari sisi kompetensi, pemenuhan kompetensi yang kompleks dalam kebijakan peningkatan disiplin dan penegakan hukum kesehatan akan sulit terpenuhi jika sumber daya perangkat daerah yang terlibat sangat terbatas. Akan berbeda jika sumber daya (PD) yang terlibat kompleks, maka kompetensi teknis terkait virus, komunikasi, sosialisasi, hukum dalam hal pemberian sanksi akan lebih cepat terpenuhi.

Tidak adanya kritikal faktor berkaitan dengan disposisi/perilaku aparatur dapat menyebabkan kurang maksimalnya proses implementasi regulasi peningkatan disiplin dan penegakan hukum protokol kesehatan, karena tidak adanya sebuah pendekatan. Disposisi berkaitan dengan watak dan karakteristik yang dimiliki oleh implementor, seperti komitmen, kejujuran, sifat demokratis. Penting di dalam regulasi peraturan kepala daerah untuk merangkul masyarakat secara partisipatif yang humanis. Watak yang mengayomi sebagai wujud birokrasi yang melayani harus tergambar di dalam regulasi. Salah satu yang diatur di dalam peraturan kepala daerah adalah terkait penerapan denda. Walaupun disahkan oleh regulasi, namun, harus menjadi pertimbangan terkait besaran yang akan ditetapkan. Jangan sampai besaran denda justru memberatkan masyarakat, terlebih dalam situasi ekonomi yang sulit seperti saat ini. Begitupun kebijakan atas kewajiban penyediaan tempat cuci tangan bagi 
warung kopi, pedagang kaki lima, ataupun pasar tradisional. Dengan kondisi lapak yang sudah sangat terbatas, akan lebih bijak bagi pemerintah daerah untuk mengatur tentang penyediaan fasilitas tempat cuci tangan di beberapa titik. Apabila implementor memiliki disposisi yang baik, maka dia akan dapat menjalankan kebijakan dengan baik seperti apa yang diinginkan oleh pembuat kebijakan (Subarsono dalam Zahrah dan Hidayat, 2017).

Adapun tidak adanya kritikal faktor terkait struktur otganisasi dapat menyebabkan eksekusi kebijakan di lapangan menjadi tidak maksimal. Koordinasi yang intens terkait peran masing-masing perangkat daerah dalam penerapan Peraturan Kepala Daerah terkait peningkatan disiplin dan penegakan protokol kesehatan harus dilakukan guna mempermudah pelaksanaan kegiatan di lapangan. Tanpa adannya koordinasi, sebaik apapun program/kegiatan yang sudah didesain, dapat macet/gagap di tengah jalan karena ketidak jelasan peran masing-masing perangkat daerah. Implementasi yang berhasil merupakan fungsi dari kemampuan organisasi pelaksana untuk melakukan apa yang diharapkan untuk dikerjakan (Van Meter dan Van Horn dalam Winarno, 2012 : 173174). Adanya prosedur operasi yang standar (Standard Operating Procedures atau SOP) dalam proses implementasi kebijakan sangat penting. Dalam kegiatan implemantasi kebijakan, struktur organisasi merupakan wadah atau wahana interaksi dimana para petugas, aparat birokrasi, atau pejabat yang berwenang mengelola implementasi kebijakan dengan berbagai kebijakannya (Purwanto dan Sulistyastuti, 2012 : 130).Guna mengimplementasikan substansi regulasi peningkatan disiplin dan penegakan hukum protokol kesehatan di lingkungan pemerintah daerah, penting untuk menentukan dengan jelas terkait standar prosedur akan denda dan sanksi,sehingga jelas pelaksanaannya di lapangan. Di beberapa peraturan bupati yang menjadi lokus penelitian, ruang lingkup implementasi terkait komunikasi, sumber daya, perilaku, dan struktur organisasi masih ada yang belum diatur secara jelas, sehingga tidak diketahui siapa yang harus bertanggung jawab dalam setiap tahapan serta kepada siapa akhir alur dari denda dan sanksi. Dengan substansi yang tidak efektif, wajar jika pelanggaran atas regulasi kepala daerah tentang peningkatan disiplin penegakan hukum protokol kesehatan masih banyak dilanggar dan diacuhkan. Secara lebih jelas, berikut matriks pemetaan efektivitas substansi Perbup terkait pemenuhan kritikal faktor dari Implementasi kebijakan yang menjadi objek penelitian : 


\begin{tabular}{|c|c|c|c|c|c|c|}
\hline \multirow[b]{2}{*}{ Regulasi } & \multicolumn{4}{|c|}{ Kritikal Faktor } & \multicolumn{2}{|c|}{ Efektivitas } \\
\hline & Komunikasi & $\begin{array}{c}\text { Sumber } \\
\text { daya }\end{array}$ & Perilaku & $\begin{array}{c}\text { Struktur } \\
\text { Organisasi }\end{array}$ & $\begin{array}{l}\text { Efe } \\
\text { ktif }\end{array}$ & $\begin{array}{l}\text { Bel } \\
\text { um } \\
\text { efe } \\
\text { ktif }\end{array}$ \\
\hline $\begin{array}{l}\text { Perbup } \\
\text { Belitung } \\
\text { Timur No. } \\
\text { 44 Tahun } \\
2020 \\
\text { Tentang } \\
\text { Penerapan } \\
\text { Disiplin dan } \\
\text { Penegakan } \\
\text { Hukum } \\
\text { protokol } \\
\text { Kesehatan } \\
\text { Sebagai } \\
\text { Upaya } \\
\text { Pencegahan } \\
\text { dan } \\
\text { pengendalia } \\
\text { n Covid-19 } \\
\text { di } \\
\text { Kabupaten } \\
\text { Belitung } \\
\text { Timur }\end{array}$ & $\begin{array}{l}\text { - Sosialisasi } \\
\text { melibatkan } \\
\text { Forkumpim } \\
\text { da, instansi } \\
\text { vertikal, } \\
\text { Pemdes, } \\
\text { masyarakat, } \\
\text { pemuka } \\
\text { agama, } \\
\text { tokoh } \\
\text { masyarakat, } \\
\text { tokoh adat, } \\
\text { LSM, unsur } \\
\text { masyarakat } \\
\text { lainnya dan } \\
\text { edukasi } \\
\text { berbagai } \\
\text { media } \\
\text { - Sosialisasi } \\
\text { melibatkan } \\
\text { Forkumpim } \\
\text { da, instansi } \\
\text { vertikal, } \\
\text { Pemdes, } \\
\text { masyarakat, } \\
\text { pemuka } \\
\text { agama, } \\
\text { tokoh } \\
\text { masyarakat, } \\
\text { tokoh adat, } \\
\text { LSM, unsur } \\
\text { masyarakat } \\
\text { lainnya dan } \\
\text { edukasi } \\
\text { berbagai } \\
\text { media }\end{array}$ & $\begin{array}{l}\text { Terdapat } 17 \\
\text { (Tujuh Belas) } \\
\text { OPD yang } \\
\text { dilibatkan } \\
\text { dalam Monev } \\
\text { pelaksanaan } \\
\text { pantauan }\end{array}$ & $\begin{array}{l}\text { Dalam } \\
\text { pelaksanaan } \\
\text { penegakan } \\
\text { penerapan } \\
\text { sanksi, Satpol } \\
\text { PP wajib } \\
\text { menyebar } \\
\text { luaskan } \\
\text { informasi } \\
\text { kepada } \\
\text { masyarakat } \\
\text { yang Dinas } \\
\text { dikoordinasikan } \\
\text { dengan Dinas } \\
\text { Komunikasi dan } \\
\text { Informatika } \\
\text { paling lambat } 3 \\
\text { hari sebelum } \\
\text { operasi/razia } \\
\text { dilaksanakan } \\
\text { Dalam } \\
\text { pelaksanaan } \\
\text { penegakan } \\
\text { penerapan } \\
\text { sanksi, Satpol } \\
\text { PP wajib } \\
\text { menyebar } \\
\text { luaskan } \\
\text { informasi } \\
\text { kepada } \\
\text { masyarakat } \\
\text { yang dikoordinasikan } \\
\text { dengan Dinas } \\
\text { Komunikasi dan } \\
\text { Informatika } \\
\text { paling lambat } 3 \\
\text { hari sebelum } \\
\text { operasi/razia } \\
\text { dilaksanakan }\end{array}$ & $\begin{array}{l}\text { Sanksi kerja } \\
\text { sosial } \\
\text { dilakukan/ } \\
\text { dikoordinasikan } \\
\text { oleh OPD } \\
\text { Dinsos pemberdayaan } \\
\text { masyarakat } \\
\text { Desa. } \\
\\
\text { Pelaksanaan } \\
\text { denda dilakukan } \\
\text { oleh Jaksa } \\
\text { sesuai atturan } \\
\text { dan disetorkan } \\
\text { ke rekening kas } \\
\text { negara yang } \\
\text { dikoordinasikan } \\
\text { dengan Badan } \\
\text { pengelolaan } \\
\text { Keuangan dan } \\
\text { Pendapatan } \\
\text { Daerah }\end{array}$ & $V$ & \\
\hline
\end{tabular}




\begin{tabular}{|c|c|c|c|c|c|c|}
\hline \multirow[b]{2}{*}{ Regulasi } & \multicolumn{4}{|c|}{ Kritikal Faktor } & \multicolumn{2}{|c|}{ Efektivitas } \\
\hline & Komunikasi & $\begin{array}{c}\text { Sumber } \\
\text { daya }\end{array}$ & Perilaku & $\begin{array}{c}\text { Struktur } \\
\text { Organisasi }\end{array}$ & $\begin{array}{l}\text { Efe } \\
\text { ktif }\end{array}$ & $\begin{array}{l}\text { Bel } \\
\text { um } \\
\text { efe } \\
\text { ktif }\end{array}$ \\
\hline $\begin{array}{l}\text { Perbup } \\
\text { Bone No. } \\
37 \text { Tahun } \\
2020 \\
\text { Tentang } \\
\text { penerapan } \\
\text { Disiplin dan } \\
\text { Penegakan } \\
\text { Hukum } \\
\text { Protokol } \\
\text { Kesehatan } \\
\text { Sebagai } \\
\text { Upaya } \\
\text { pencegahan } \\
\text { dan } \\
\text { pengendalia } \\
\text { n Covid-19 } \\
\text { di } \\
\text { kabupaten } \\
\text { Bone }\end{array}$ & $\begin{array}{l}\text { Pelaksanaan } \\
\text { sosialisasi } \\
\text { melalui } \\
\text { Forkumpimda } \\
\text { dan masyarakat } \\
\text { yang terdiri } \\
\text { atas : tokoh } \\
\text { masyarakat, } \\
\text { pemuka agama, } \\
\text { tokoh adat, } \\
\text { tokoh pemuda, } \\
\text { dan unsur } \\
\text { masyarakat } \\
\text { lain. Dalam } \\
\text { pelaksnanaan } \\
\text { sosialisasi, } \\
\text { bupati dapat } \\
\text { membentuk tim } \\
\text { sosialisasi }\end{array}$ & $\begin{array}{l}\text { Tersebut di } \\
\text { dalam perbup } \\
\text { Dinkes dan } \\
\text { Instansi terkait } \\
\text { (tanpa } \\
\text { penjelasan } \\
\text { rinci siapa saja } \\
\text { instansi terkait } \\
\text { di dalam } \\
\text { perbup) }\end{array}$ & $\begin{array}{l}\text { Belum } \\
\text { tergambarkan } \\
\text { secara spesifik } \\
\text { pendekatan } \\
\text { persuasif yang } \\
\text { akan dilakukan } \\
\text { oleh } \\
\text { implementator }\end{array}$ & $\begin{array}{l}\text { Belum } \\
\text { tergambarkan } \\
\text { secara eksplisit } \\
\text { tentang standar } \\
\text { operasional } \\
\text { prosedur antar } \\
\text { PD }\end{array}$ & & $V$ \\
\hline $\begin{array}{l}\text { Perbup } \\
\text { Boalemo } \\
\text { No. } 60 \\
\text { Tahun } 2020 \\
\text { Tentang } \\
\text { Penerapan } \\
\text { Disiplin dan } \\
\text { Penegakan } \\
\text { Hukum } \\
\text { Protokol } \\
\text { Kesehatan } \\
\text { Sebagai } \\
\text { Upaya } \\
\text { Pencegahan } \\
\text { dan } \\
\text { Pengendalia } \\
\text { n Covid-19 }\end{array}$ & $\begin{array}{l}\text { Dalam } \\
\text { melaksanakan } \\
\text { sosialisasi } \\
\text { melibatkan } \\
\text { Forum } \\
\text { Komunikasi } \\
\text { Pimpinan } \\
\text { Daerah dan } \\
\text { Partisipasi serta } \\
\text { peran serta } \\
\text { yaitu : } \\
\text { masyarakat, } \\
\text { pemuka agama, } \\
\text { tokoh adat, } \\
\text { tokoh } \\
\text { masyarakat ; } \\
\text { dan unsur } \\
\text { masyarakat } \\
\text { lainnya }\end{array}$ & $\begin{array}{l}\text { Bupati } \\
\text { menugaskan } \\
\text { dinas yang } \\
\text { membidangi } \\
\text { kesehatan } \\
\text { untuk } \\
\text { melakukan } \\
\text { sosialisasi } \\
\text { terkait } \\
\text { informasi/ } \\
\text { edukasi cara } \\
\text { pencegahan } \\
\text { dan } \\
\text { pengendalian } \\
\text { Covi d - } 19 \\
\text { terhadap } \\
\text { Masyarakat . }\end{array}$ & $\begin{array}{l}\text { Belum } \\
\text { tergambarkan } \\
\text { secara spesifik } \\
\text { pendekatan } \\
\text { persuasif yang } \\
\text { akan dilakukan } \\
\text { oleh } \\
\text { implementator }\end{array}$ & $\begin{array}{l}\text { Dinas Satuan } \\
\text { Polisi Pamong } \\
\text { Praja, Dinas } \\
\text { Kesehatan, } \\
\text { BPBD dan } \\
\text { Satker terkait } \\
\text { lainnya untuk } \\
\text { melakukan } \\
\text { monitoring dan } \\
\text { evaluasi }\end{array}$ & & $V$ \\
\hline
\end{tabular}




\begin{tabular}{|c|c|c|c|c|c|c|}
\hline \multirow[b]{2}{*}{ Regulasi } & \multicolumn{4}{|c|}{ Kritikal Faktor } & \multicolumn{2}{|c|}{ Efektivitas } \\
\hline & Komunikasi & $\begin{array}{c}\text { Sumber } \\
\text { daya }\end{array}$ & Perilaku & $\begin{array}{c}\text { Struktur } \\
\text { Organisasi }\end{array}$ & $\begin{array}{l}\text { Efe } \\
\text { ktif }\end{array}$ & $\begin{array}{l}\text { Bel } \\
\text { um } \\
\text { efe } \\
\text { ktif }\end{array}$ \\
\hline $\begin{array}{l}\text { Perbup } \\
\text { Klaten No. } \\
40 \text { Tahun } \\
2020 \\
\text { Tentang } \\
\text { Penerapan } \\
\text { Disiplin dan } \\
\text { Penegakan } \\
\text { Hukum } \\
\text { Protokol } \\
\text { Kesehatan } \\
\text { Sebagai } \\
\text { Upaya } \\
\text { Pencegahan } \\
\text { dan } \\
\text { Pengendalia } \\
\text { n Covid-19 } \\
\text { di } \\
\text { kabupaten } \\
\text { Klaten }\end{array}$ & $\begin{array}{l}\text { Dalam } \\
\text { melaksanakan } \\
\text { sosialisasi } \\
\text { melibatkan : } \\
\text { masyarakat, } \\
\text { tokoh } \\
\text { masyarakat; } \\
\text { tokoh agama, } \\
\text { unsur } \\
\text { masyarakat } \\
\text { lainnya }\end{array}$ & $\begin{array}{l}\text { Bupati } \\
\text { menugaskan } \\
\text { BPPD, } \\
\text { Dinnkes, } \\
\text { Dishub, Satpol } \\
\text { PP, dan PD } \\
\text { yang } \\
\text { membidangi } \\
\text { Kesbangpol } \\
\text { untuk } \\
\text { Monitoring }\end{array}$ & $\begin{array}{l}\text { Pembinaan } \\
\text { dilakukan } \\
\text { dengan } \\
\text { sosialisasi, } \\
\text { advokasi, } \\
\text { pemberian } \\
\text { bimbingan/ } \\
\text { pelatihan dan } \\
\text { pemantauan } \\
\text { lapangan. } \\
\text { melakukan } \\
\text { inspeksi } \\
\text { perkantoran/ } \\
\text { tempat } \\
\text { kerja,disamping } \\
\text { tempat usaha, } \\
\text { fasilitas umum, } \\
\text { tempat wisata, } \\
\text { serta tempat - } \\
\text { tempat lain } \\
\text { yang digunakan } \\
\text { untuk kegiatan } \\
\text { pertemuan } \\
\text { akbar dan } \\
\text { perhelatan } \\
\text { pertunjukan } \\
\text { seni/budaya dan } \\
\text { kegiatan } \\
\text { olahraga. }\end{array}$ & $\begin{array}{l}\text { Prosedur } \\
\text { koordinasi } \\
\text { jelas, mulai } \\
\text { dari } \\
\text { koordinasi, } \\
\text { pelaksanaan } \\
\text { tugas personil, } \\
\text { pemberian } \\
\text { pengarahan, } \\
\text { hingga } \\
\text { membuat } \\
\text { berita acara. }\end{array}$ & $V$ & \\
\hline $\begin{array}{l}\text { Perbup } \\
\text { Situbondo } \\
\text { No. 45 } \\
\text { Tahun } 2020 \\
\text { Tentang } \\
\text { Penerapan } \\
\text { Disiplin dan } \\
\text { Penegakan } \\
\text { Hukum } \\
\text { Protokol } \\
\text { Kesehatan } \\
\text { Sebagai } \\
\text { Upaya } \\
\text { Pencegahan } \\
\text { dan } \\
\text { Pengendalia } \\
\text { n Covid-19 } \\
\text { di } \\
\text { kabupaten } \\
\text { Situbondo }\end{array}$ & $\begin{array}{l}\text { Pelaksanaan } \\
\text { Sosialisasi dan } \\
\text { penyebaran } \\
\text { informasi } \\
\text { melibatkan } \\
\text { Forkumpimda } \\
\text { dan peran } \\
\text { serta : ormas, } \\
\text { organisasi } \\
\text { profesi, } \\
\text { pemuka agama, } \\
\text { tokoh adat, } \\
\text { tokoh } \\
\text { masyarakat, } \\
\text { unsur } \\
\text { masyarakat } \\
\text { lain. }\end{array}$ & $\begin{array}{l}\text { Satpol PP, PD } \\
\text { yang } \\
\text { membidangi } \\
\text { kesehatan, } \\
\text { DPMPTSP, } \\
\text { Satpol PP, PD } \\
\text { terkait, Tim } \\
\text { yang dibentuk } \\
\text { dengan } \\
\text { Keputusan } \\
\text { Bupati }\end{array}$ & $\begin{array}{l}\text { Bupati } \\
\text { menugaskan } \\
\text { Diskominfo } \\
\text { untuk menyebar } \\
\text { luaskan } \\
\text { informasi atas } \\
\text { Perbup ini } \\
\text { kepada } \\
\text { masyarakat. }\end{array}$ & $\begin{array}{l}\text { Sebelum } \\
\text { dilaksanakan } \\
\text { operasi dan/ } \\
\text { atau inspeksi, } \\
\text { koordinator } \\
\text { operasi dan } \\
\text { atau/ } \\
\text { koordinator } \\
\text { inspeksi } \\
\text { melaksnakan } \\
\text { apel dan } \\
\text { memberikan } \\
\text { pengarahan } \\
\text { dan } \\
\text { pembekalan } \\
\text { kepada } \\
\text { seluruh } \\
\text { personel yang } \\
\text { bertugas }\end{array}$ & $V$ & \\
\hline
\end{tabular}

Sumber : Peraturan Bupati Bone No.37Tahun 2020, Peraturan Bupati Belitung Timur No. 44 Tahun 2020, Peraturan Bupati Boalemo No. 60 Tahun 2020, Peraturan Bupati Klaten No. 40 Tahun 2020, dan Peraturan Bupati Situbondo No. 45 Tahun 2020 
Berdasarkan Tabel Pemetaan Efektivitas dari Faktor Implementasi Kebijakan dalam Peraturan Bupati, diharapkan dapat membantu pemerintah daerah untuk memberikan gambaran tentang peraturan bupati yang efektif terkait peningkatan disiplin dan penegakan hukum protokol kesehatan. Efektifitas yang didapatkan dari hasil analisis implementasi, diharapkan dapat membantu mempermudah operasionalisasi semua peraturan kepala daerah yang sudah diterbitkan di seluruh Indonesia. Dengan adanya pemenuhan empat kritikal faktor implementasi sebagaimana yang disampaikan oleh Edward III, diharapkan tidak akan menimbulkan celah interprestasi dan kegagapan dalam hal koordinasi yang dapat menyebabkan kebingungan dalam pelaksanaan di lapangan. Dengan substansi yang jelas, peraturan kepala daerah diharapkan dapat efektif dan berkontribusi besar dalam upaya mengurangi angka penyebaran Covid-19. Pelanggaran terhadap peningkatan disiplin dan penegakan protokol kesehatan Covid-19 dapat diminimalisir, karena setiap sumber daya daerah (perangkat daerah) memahami akan tugasnya masing-masing dalam memitigasi penyebaran Covid-19.

\section{PENUTUP}

\section{Kesimpulan}

Guna memotret efektivitas peraturan kepala daerah (perbup) terkait peningkatanan disiplin dan penegakan hukum protokol kesehatan, dapat dilakukan melalui peraturan kepala daerah yang menjadi objek penelitian. Analisis terhadap efektifitas peraturan kepala daerah didasarkan pada terakomodasi atau tidaknya konsep sebuah implementasi kebijakan di dalamnya. Berkurangnya salah satu kritikal faktor dapat menyebabkan kegagapan dalam implementasi peraturan kepala daerah. Dari hasil analisis, masih terdapat beberapa peraturan kepala daerah (Peraturan Bupati) yang belum efektif secara substansi. Ketidak efektifan peraturan kepala daerah tersebut, karena belum mengakomodasi empat kritikal faktor yang dijadikan alat analisis dalam peneltian ini, yakni : komunikasi, sumber daya, perilaku, dan struktur organisasi.

\section{Saran}

Dengan adanya peraturan kepala daerah (perbup) yang belum efektif secara substansi, ,maka perlu dicarikan solusi agar tidak terdapat celah hukum yang dapat mengganggu efektivitas implementasinya. Mengganti peraturan bupati, tentu tidak mudah, walaupun pembuatan peraturan bupati hanya bersifat 'internal'. Agar peraturan bupati tersebut dapat tetap diterapkan, tanpa mengubahnya, maka, upaya yang dapat dilakukan adalah mengakomodasi substansi yang belum ada ke dalam produk hokum/produk kebijakan yang lebih teknis seperti melalui penerbitan surat keputusan, surat edaran, ataupun nota dinas yang berisikan hal-hal yang belum terakomodasi di dalam peraturan bupati tersebut. Produk hukum/produk kebijakan tersebut diharapkan dapat melengkapi Perbup dengan mengisi kekosongan substansi yang seharusnya tersebut di dalam regulasi peraturan bupati yang sudah terbit.

\section{Daftar Pustaka}

Afrizal, 2015, Metode Penelitian Kualitatif (Sebuah Upaya Mendukung Penggunaan Penelitian Kualitatif Dalam Berbagai Disiplin Ilmu), Cetakan kedua, PT. RajaGrafindo Persada, Jakarta

Arundinasari, I., Makmur, M., \& Wanto, A. H. 2020. Implementasi Peraturan Daerah Kabupaten Gresik Nomor 23 Tahun 2004 tentang Retribusi Izin Mendirikan Bangunan (Studi pada Dinas Penanaman Modal Pelayanan Terpadu Satu Pintu Kabupaten Gresik). Jurnal Ilmiah Administrasi Publik, 5(3), 337-343. https:// jiap.ub.ac.id/index.php/jiap/article/ view/903

Dewa, Jufri, Muh, 2011, Hukum Administrasi Negara (Dalam Perspektif Pelayanan Publik), 
Unhalu Press, Kendari

Engkus, Suparman. Nanang, Sakti. Tri. Fajar, Anwar. Saeful. Husen LP2M (2020), COVID-19: Kebijakan Mitigasi Penyebaran Dan Dampak Sosial Ekonomi Di Indonesia, http:// digilib.uinsgd.ac.id/30820/, di download tanggal 23 Oktober 2020

Hardilawati . Laura. Wan, 2020, Strategi Bertahan UMKM di Tengah Pandemi Covid -19, Jurnal Akuntansi \& Ekonomika, Vol. 10 No. Juni 2020, http:// www.ejurnal.umri.ac.id/index.php/ jae/article/view/1934

Harirah MS, Zulfa 2020, Merespon Nalar Kebijakan Negara Dalam Menangani Pandemi covid 19 di Indonesia, Jurnal Ekonomi dan Kebijakan Publik Indonesia: Volume 7, No. 1, Mei 2020 ISSN: 2442-741, di download 23 Oktober 2020

Lestanata, Y., \& Pribadi, U, 2016, Efektivitas Pelaksanaan Program Pembangunan Berbasis Rukun Tetangga Di Kabupaten Sumbawa Barat Tahun 2014-2015, Journal of Governance and Public Policy, 3 (3), 368-389

Kurniawan, R., Alexandri, M. B., \& Nurasa, H. 2018. IMSTeP: Indonesian Marine Science And Techno Park Implementasi Kebijakan Model Van Meter Dan Van Horn Di Indonesia. Responsive: Jurnal Pemikiran Dan Penelitian Administrasi, Sosial, Humaniora Dan Kebijakan Publik, 1(1), 34-38. http://journal.unpad.ac.id/ responsive/article/view/19098/8927

Mugni, Abdul dan Harjoni, 2020, Strategi Komunikasi dalam Sosialisasi Kebijakan Penghapusan Human Trafficking di Kota Lhokseumawe, Jurnal Ultimacomm Vol. 12, No. 1, June 2020, ISSN: 2085 - 4609 (Print), e- ISSN 2656-0208

Pradana. Ahadi. Anung, Casman, Nur'aini, 2020, Pengaruh Kebijakan Social Distancing Pada Wabah Covid-19
Terhadap Kelompok Rentan Di Indonesia, Jurnal Kebijakan Kesehatan Indonesia : JKKI, Vol. 09, No. 02 Juni 2020

Purwanto , Agus,Erwan dan Sulistyastuti, Ratih, Dyah, , 2012, Implementasi Kebijakan Publik, Konsep dan Aplikasinya di Indonesia, Gava Media, Yogyakarta

Purworini, D. (2017), Model informasi publik di era media sosial: Kajian grounded teori di pemda sukoharjo, Komuniti: Jurnal Komunikasi dan Teknologi Informasi, 6(1), 3-14 http:// journals.ums.ac.id/index.php/ komuniti/article/view/2929, di download 15 Oktober 2020

Ryndang. Darwaty. Lona. Mercy, 2020, Performa Komunikatif Pemerintah Dalam Melakukan Sosialisasi Kebijakan Publik Amnesti Pajak, Sriganda Communications Vol. 2 No. 2 Juli 2020, , DOI:https:// doi.org/10.21009/

Communications.2.2.1

Silalahi, Ulber, Komunikasi Pemerintahan: Mengirim Dan Menerima Informasi Tugas Dan Informasi Publik http:// journal.unpar.ac.id/index.php/JAP/ article/view/652 di download 15 Oktober 2020

Tuwu, Darmin, 2020, Kebijakan Pemerintah Dalam Penanganan Pandemi Covid-19, Journal Publikuho ISSN 2621-1351 (online), ISSN 2685-0729 (print) Volume 3 Number 2 (May-July), (2020) pp.267 -278

Winarno, Budi, 2012, Kebijakan Publik (Teori, Proses, dan Studi Kasus), CAPS, Yogyakarta

Zahrah, Zahirah dan Hidayat, Z. 2017, Implementasi Program Kelurahan Siaga Bencana (KSB) di Kecamatan Ngaliyan Kota Semarang, Journal of Publik Policy and Management Review, 6(2), 88100

https://republika.co.id/berita/qh59ms370/ jumlah-pelanggar-protokolkesehatan-di-kudus-capai-4574 
Arti New Normal Indonesia: Tatanan Baru Beradaptasi dengan COVID19, https://irto.id/arti-new-normalindonesia-tatanan-baru-beradaptasi -dengan-covid-19-fDB3, diunduh 25 Oktober 2020

Covid-19, Kerentanan Sosial, dan Gagalnya Physical Distancing, https://kolom.tempo.co/ read/1326074/covid-19-kerentanan -sosial-dan-gagalnya-physicaldistancing, didownload - an 12 Oktober 2020

Update Corona 11 Oktober: 333.449 Positif, 11.844 Meninggal, https:// www.cnnindonesia.com/ nasional/20201010204704-20556931/update-corona-11-oktober333449-positif-11844-meninggal

https://www.liputan6.com/health/ read/4377340/kasus-positif-covid19-di-indonesia-bertambah-4850per-8-oktober-2020, Didownload pada tanggal 12 Oktober 2020

https://www.liputan6.com/news/ read/4324705/jubir-inpres-nomor-6 -tahun-2020-bukti-keseriusan-tekan -penyebaran-covid-19 https:

Jumlah Pelanggar Protokol Kesehatan Terus Bertambah https:// riaupos.jawapos.com/ riau/14/08/2020/236451/jumlahpelanggar-protokol-kesehatan-terus -bertambah.html, didownload 15 Oktober 2020

Komunikasi soal Covid-19 Dinilai Bermasalah, Masyarakat Gagal Paham https://www.kompas.com/ tren/read/2020/06/26/192700865/ komunikasi-soal-covid-19-dinilaibermasalah-masyarakat-gagalpaham?page $=$ all

Perbedaan Keputusan Presiden dengan Instruksi Presiden, https:// www.hukumonline.com/klinik/ detail/ulasan/lt50cf39774d2ec/ peraturan-presiden/, di download tanggal 22 Oktober 2020

https://health.detik.com/berita-detikhealth/ d-5074173/kilas-balik-6-bulanpandemi-corona-lebih-dari-10-jutaorang-sudah-terinfeksi

https://tirto.id/grafik-kasus-covid-19- dianggap-jahat-rawan-tanpapenjelasan-f8Bx

https://tirto.id/kematian-meninggi-tandapenularan-covid-19-makin-takterkendali-f8a4,didownload tanggal 20 Desember 2020

Survey Angkatan Kerja Nasional BPS, Booklet Agustus 2019. https:// www.bps.go.id/ publication/2019/12/10/680c34c3a8c4955 c235892c9/booklet-survei-angkatan-kerjanasional-agustus-2019.html 